\title{
Status Sosial Ekonomi dan Keragaman Pangan Pada Balita Stunting dan Non- Stunting Usia 24-59 Bulan di Wilayah Kerja Puskesmas Wilangan Kabupaten Nganjuk
}

\section{Socio-Economic Status and Dietary Diversity in Stunting and Non-Stunting Underfive Aged 24-59 Months in Wilangan Health Center Working Area of Nganjuk Regency}

\author{
Atin Nurmayasanti*1, Trias Mahmudiono²
}

\begin{abstract}
ABSTRAK
Latar Belakang: Stunting adalah masalah gizi kronis yang disebabkan oleh asupan gizi yang kurang dan penyakit infeksi. Penyebab lain adalah kondisi sosial ekonomi dan gizi ibu saat hamil. Kualitas gizi pada makanan dipengaruhi oleh keragaman jenis pangan yang dikonsumsi. Keragaman pangan dapat ditentukan oleh kesejahteraan, usia anak, dan pendidikan ibu. Kondisi ekonomi memiliki risiko terjadinya stunting karena dapat menggambarkan kemampuan keluarga dalam memenuhi asupan makanan yang bergizi.

Tujuan: Penelitian ini bertujuan untuk menganalisis hubungan antara sosial ekonomi dan keragaman pangan dengan kejadian stunting pada balita usia 24-59 bulan.

Metode: Penelitian ini adalah jenis penelitian observasional dengan desain penelitian case control. Populasi pada penelitian ini anak balita usia 24-59 bulan yang terdaftar dalam Posyandu wilayah kerja Puskesmas Wilangan. Besar sampel yang diambil masing-masing 28 balita yang dipilih melalui simple random sampling. Skor keragaman pangan diperoleh dari skor Individual Dietary Diversity Score (IDDS). Analisis data secara deskriptif untuk menggambarkan usia balita, jenis kelamin, pendidikan ibu, dan pekerjaan ibu. Sedangkan analisis inferensial menggunakan uji chi-square untuk mengetahui hubungan keragaman pangan dan tingkat pendapatan dengan kejadian stunting.

Hasil: Hasil penelitian menunjukkan pendapatan keluarga berhubungan dengan kejadian stunting pada balita $(p=0,048)$. Pendapatan keluarga yang rendah berisiko terkena stunting. Skor keragaman pangan pangan balita stunting maupun nonstunting sama-sama masih rendah. Hasil chi-square menunjukkan bahwa tidak ada hubungan antara keragaman pangan dengan kejadian stunting ( $p=1,000)$ dan bukanlah faktor risiko balita stunting $(\mathrm{OR}=1,000)$.

Kesimpulan: Pendapatan keluarga memiliki hubungan yang signifikan dengan kejadian stunting. Keragaman pangan tidak berhubungan dengan stunting.
\end{abstract}

Kata kunci: tingkat pendapatan, keragaman pangan, stunting

\section{ABSTRACT}

Background: Stunting is a chronic nutritional problem caused by poor nutritional intake and infectious diseases. Other causes are maternal socio-economic and nutritional conditions during pregnancy. Nutritional quality in food is influenced by the diversity of types of food consumed. Food diversity can be determined by prosperity, children's age, and mother's education. Economic conditions have a risk of stunting because they can describe the family's ability to fulfill nutritious food intake.

Objective: This study aimed to analyze the relationship between socio-economic and food diversity with the incidence of stunting in children aged 24-59 months.

Method: This study was an observational study with case control research design. The population in this study were children aged 24-59 months who were enrolled in Posyandu in the Puskesmas Wilangan working area. The sample size taken by each 28 toddlers was selected through simple random sampling. The food diversity score is obtained from the Individual Dietary Diversity Score (IDDS) score. Descriptive data analysis to describe toddler age, gender, mother's education, and mother's work. While inferential analysis used the chi-square test to determine the relationship between food diversity and income level with the incidence of stunting.

Results: The results showed that family income was related to the incidence of stunting in infants $(p=0.048)$. Low family income is at risk of getting stunting. Scores of food diversity for stunting and non-stunting children are still low. 
The chi-square results show that there is no relationship between food diversity and the incidence of stunting $(p=1.000)$ and not a risk factor for stunting toddlers $(O R=1.000)$.

Conclusion: Family income has a significant relationship with the incidence of stunting. Food diversity is not related to stunting.

Keywords: income level, food diversity, stunting

\author{
*Koresponden: \\ maya.anms@yahoo.com \\ 1,2Program Studi S1 Gizi, Fakultas Kesehatan Masyarakat, Universitas Airlangga \\ Kampus C Mulyorejo, 60115, Surabaya, Jawa Timur, Indonesia
}

\section{PENDAHULUAN}

Periode paling penting pertumbuhan dan perkembangan terjadi pada masa balita ${ }^{1}$. Sekitar 200 juta anak di bawah umur 5 tahun gagal untuk mencapai potensi mereka dalam perkembangan kognitif karena berbagai macam faktor risiko seperti kemiskinan, kesehatan yang rendah, pola asuh dan gizi yang tidak mencukupi². Malnutrisi berat dapat menyebabkan gizi kurang (berat badan rendah menurut umur, seringkali dikaitkan dengan kehilangan lemak dan jaringan otot yang disebabkan oleh kelaparan akut) dan stunting (tinggi badan yang rendah menurut umur, seringkali diikuti dengan rendahnya perkembangan mental dan fisik secara tetap sebagai akibat dari masalah gizi kronis) $)^{3}$.

Hasil Riskesdas tahun 2018 menunjukkan bahwa persentase balita stunting di Indonesia sebesar 30,8\% ${ }^{4}$. Di Jawa Timur angka angka stunting menunjukkan persentase sebesar $26,2 \%^{4}$. Persentase status gizi balita sangat pendek di Kabupaten Nganjuk sebesar 22,5\% sedangkan persentase anak pendek sebesar $21,8 \%{ }^{5}$. Dikatakan stunting apabila tinggi badan menurut umur kurang dari -2 SD menurut standar $\mathrm{WHO}^{6}$. Stunting mulai tampak pada saat anak berusia dua tahun dan dimulai pada saat janin masih dalam kandungan? ${ }^{7}$.

Stunting disebabkan oleh banyak faktor, diantaranya kondisi sosial ekonomi, gizi ibu saat hamil, kesakitan pada bayi, dan kurangnya asupan gizi pada bayi ${ }^{8}$. Kualitas gizi pada makanan itu sendiri dipengaruhi oleh keragaman jenis pangan yang dikonsumsi ${ }^{9}$. Keanekaragaman pangan adalah macam kelompok pangan terdiri dari makanan pokok, lauk pauk, sayuran, buah-buahan dan air serta bermacam jenis pangan dalam setiap kelompok pangan ${ }^{9}$. Penelitian di Ethiopia menunjukkan adanya hubungan yang signifikan antara keragaman pangan dengan kejadian stunting ${ }^{10}$. Kesejahteraan, usia anak, dan pendidikan ibu diidentifikasi sebagai penentu keanekaragaman makanan anak ${ }^{11}$. Kondisi ekonomi berkaitan erat dengan risiko terjadinya stunting karena dari kondisi ekonomi akan terlihat bagaimana kemampuan keluarga dalam memenuhi asupan makanan yang bergizi ${ }^{8}$. Hasil penelitian di Kabupaten Banyumas menyatakan bahwa pendapatan keluarga berhubungan dengan kejadian stunting ${ }^{12}$. Berdasarkan permasalahan tersebut perlu diteliti apakah menjadi penyebab dari masalah stunting pada balita usia 24-49 bulan. Tujuan dari penelitian ini adalah untuk menganalisis hubungan antara keragaman pangan dan status sosial ekonomi dengan kejadian stunting pada balita usia 24-59 bulan di wilayah kerja Puskesmas Wilangan Kabupaten Nganjuk.

\section{METODE}

Penelitian ini merupakan penelitian analitik observasional dengan desain case control. Penelitian dilakukan di Posyandu wilayah kerja Puskesmas Wilangan Kabupaten Nganjuk. Data dikumpulkan pada bulan April - Juli 2018. Data awal untuk mengetahui balita stunting adalah dengan menggunakan data ePPGBM (aplikasi Pencatatan dan Pelaporan Gizi Berbasis Masyarakat) dari Dinas Kesehatan Kabupaten Nganjuk yang didapat pada tanggal 1 Maret 2018 melalui survey pendahuluan. Kabupaten Nganjuk adalah satu dari 100 kabupaten atau kota lokus stunting ${ }^{13}$. Jumlah balita yang terdapat di wilayah kerja Puskesmas Wilangan sebanyak 327 balita. Dari data e-PPGBM balita stunting kemudian dilakukan skrining untuk mengetahui tinggi badan balita dalam kegiatan Posyandu di wilayah kerja Puskesmas Wilangan.

Tinggi badan balita diperoleh dari hasil pengukuran tinggi badan menggunakan microtoise dengan ketelitian $0,1 \mathrm{~cm}$. Dari hasil skrining jumlah balita stunting usia 24-59 sebanyak 71 balita dan balita normal (non-stunting) sebanyak 256 balita. Sampel penelitian adalah kelompok usia balita usia 24-59 bulan yang terdaftar di wilayah tersebut. Sampel yang digunakan sebanyak 28 untuk masing-masing kasus stunting dan non-stunting menggunakan rumus Lemeshow untuk desain penelitian case control. Pengambilan sampel menggunakan teknik sampling sederhana (simple random sampling). Kategori stunting dan non-stunting pada sampel dilihat dari nilai z-score. Termasuk kategori stunting apabila nilai Z-score <-2 SD dan non-stunting apabila nilai Z-score $\geq-2$ SD.

Berdasarkan hasil dari Komisi Etik Penelitian Kesehatan Fakultas Kesehatan Masyarakat Universitas Airlangga dengan nomor: 373-KEPK tanggal 9 Juli 2018 serta izin dari Kantor Kesatuan Bangsa Politik dan Perlindungan Masyarakat Daerah Kabupaten Nganjuk dengan nomor:072/193/411.700/2018 tanggal 21 Juni 2018, telah mendapatkan izin untuk melakukan penelitian. Pengumpulan data menggunakan metode wawancara dan observasi.

Pada penelitian ini jenis data yang digunakan adalah data primer dan data sekunder. Data primer diperoleh dari kuesioner yang terdiri dari usia balita, jenis kelamin, riwayat ASI eksklusif, makan beraneka ragam, pekerjaan ibu, pendidikan ibu dan pendapatan keluarga. Makan beraneka ragam adalah tentang 
konsumsi makanan pada balita yang diperoleh dari hasil wawancara dengan ibu atau pengasuh balita yang menggunakan formulir food recall sebanyak $3 \times 24$ jam secara tidak berurutan dengan melihat berat makanan yang dikonsumsi minimal 10 gram. Pengambilan data food recall dilakukan dalam 2 hari pada weekday dan 1 hari untuk weekend. Cara pengambilan data food recall seperti ini lebih mempresentasikan jenis makanan yang biasa dikonsumsi sehari-hari jika dibandingkan dengan pengambilan data food recall satu hari. Kemudian dari hasil data food recall tersebut dimasukkan ke dalam formulir Individual Dietary Diversity Score (IDDS) untuk melihat apakah makanan yang dikonsumsi balita beragam atau tidak dengan hasil skor rata-rata selama 3 hari. Konsumsi makan pada balita dikatakan beragam apabila IDDS menunjukkan nilai $\geq 4$ dan tidak beragam apabila nilai IDDS $<4{ }^{14}$. Data sekunder yang digunakan dalam penelitian ini berupa gambaran umum lokasi penelitian yang diperoleh dari buku profil Puskesmas. Pada penelitian ini teknik analisis data menggunakan analisis data deskriptif untuk menggambarkan variabel usia balita, jenis kelamin balita, riwayat ASI eksklusif, pendidikan ibu, dan pekerjaan ibu. Analisis inferensial menggunakan uji chi-square dengan tingkat kepercayaan 95\% untuk mengetahui hubungan pendapatan keluarga dan keragaman pangan dengan kejadian stunting serta besar risiko (nilai odds ratio) pendapatan keluarga dan keragaman pangan terhadap kejadian stunting.

Penelitian ini diuji menggunakan chi-square untuk melihat hubungan dua variabel yang berbeda dengan tingkat kepercayaan 95\%. Variabel independen yang diteliti pada penelitian ini antara lain yang dihubungkan dengan variabel dependen yaitu stunting. Selain hasil dari chi-square, penelitian ini juga melihat faktor risiko dari variabel-variabel tersebut terhadap kejadian stunting. Faktor risiko dilihat dari nilai odds ratio (OR). Gambaran keragaman konsumsi makan pada balita akan dilihat berdasarkan persentase skor dari sembilan jenis pangannya pada balita stunting dan nonstunting dengan menggunakan grafik sehingga dapat dilihat bagaimana keragaman pangan dari balita stunting dan non-stunting. Penelitian tentang keragaman pangan dengan metode penilaian IDDS pernah dilakukan sebelumnya, namun yang membedakan dengan penelitian ini adalah pemilihan sampel penelitian. Pada penelitian ini sampel penelitian akan dilihat bagaimana keragaman pangan antara balita stunting dan nonstunting di salah satu wilayah lokus atau prioritas stunting. Sedangkan penelitian terdahulu melihat perbedaan keragaman pangan balita dilihat antara wilayah satu dengan wilayah lainnya.

\section{HASIL DAN PEMBAHASAN}

Pada penelitian ini, karakteristik balita dilihat dari usia balita, jenis kelamin dan riwayat ASI eksklusif. Berdasarkan tabel 1, usia balita yang paling banyak mengalami stunting adalah usia 37-59 bulan yaitu sebanyak $30,4 \%$. Begitu juga dengan balita yang normal atau tidak stunting, persentase paling banyak terlihat pada balita usia 37-59 bulan (37,5\%). Stunting mencerminkan masalah gizi sejak periode pertumbuhan dan perkembangan paling cepat sejak awal kehidupan ${ }^{15}$. Kegagalan pertumbuhan sebagian besar terjadi dari tiga bulan hingga 18 sampai 24 bulan $^{16}$. Sehingga apabila sudah mengalami stunting di usia lebih dari 24 bulan akan sulit untuk mengejar pertumbuhan. Hasil penelitian lain menunjukkan bahwa apabila pertumbuhan anak berhenti pada usia 12 bulan dia akan dapat mencapai -2 SD setelah hampir 6 bulan atau pada usia 17,7 bulan untuk mencapai point yang sama ${ }^{17}$. Pada banyak penelitian ditemukan bahwa tinggi badan menurut umur mendekati standar saat bayi, akan tetapi mengalami penurunan tajam hingga usia dua tahun ${ }^{16}$. Penelitian di Filipina juga menyebutkan apabila pertumbuhan sudah terhambat di usia 24 bulan misalnya, pertumbuhan cenderung mulai terhambat di usia yang jauh lebih awal ${ }^{18}$. Tabel 1 menunjukkan balita perempuan cenderung lebih banyak mengalami stunting $(30,4 \%)$ daripada balita laki-laki $(19,6 \%)$. Namun persentase balita perempuan kelompok non-stunting juga menunjukkan angka yang sama dengan balita perempuan stunting.

Tabel 1. Karakteristik Balita dan Keluarga pada Kelompok Stunting dan Non-Stunting

\begin{tabular}{|c|c|c|c|c|c|c|c|c|}
\hline \multirow[b]{2}{*}{ Variabel } & \multicolumn{2}{|c|}{ Stunting } & \multicolumn{2}{|c|}{ Non-Stunting } & \multicolumn{2}{|c|}{ Total } & \multirow[b]{2}{*}{$\begin{array}{c}\text { p- } \\
\text { value }\end{array}$} & \multirow{2}{*}{$\begin{array}{c}\text { OR } \\
(95 \% \mathrm{Cl})\end{array}$} \\
\hline & $\mathrm{n}$ & $\%$ & $\mathrm{~N}$ & $\%$ & $\mathrm{n}$ & $\%$ & & \\
\hline \multicolumn{9}{|l|}{ Usia Balita } \\
\hline 24-36 bulan & 11 & 19,6 & 7 & 12,5 & 18 & 32,1 & 0,252 & 0,515 \\
\hline 37-59 bulan & 17 & 30,4 & 21 & 37,5 & 38 & 67,9 & & $(0,164-1,616)$ \\
\hline \multicolumn{9}{|l|}{ Jenis Kelamin Balita } \\
\hline Laki-laki & 11 & 19,6 & 11 & 19,6 & 22 & 39,2 & 1,000 & 1,000 \\
\hline Perempuan & 17 & 30,4 & 17 & 30,4 & 34 & 60,8 & & $(0,342-2,923)$ \\
\hline \multicolumn{9}{|l|}{ Riwayat ASI } \\
\hline Non-Eksklusif & 17 & 30,4 & 18 & 32,1 & 35 & 62,5 & 0,783 & 0,859 \\
\hline Eksklusif & 11 & 19,6 & 10 & 17,9 & 21 & 37,5 & & $(0,291-2,536)$ \\
\hline \multicolumn{9}{|l|}{ Pendidikan Ibu } \\
\hline Dasar & 16 & 28,6 & 16 & 28,6 & 32 & 57,1 & 1,000 & 1,000 \\
\hline Menengah & 12 & 21,4 & 12 & 21,4 & 24 & 42,9 & & $(0,347-2,882)$ \\
\hline \multicolumn{9}{|l|}{ Pekerjaan Ibu } \\
\hline \multirow[t]{2}{*}{ Tidak Bekerja Bekerja } & 20 & 35,7 & 23 & 41,1 & 43 & 76,8 & 0,342 & 0,543 \\
\hline & 8 & 14,3 & 5 & 8,9 & 13 & 23,2 & & $(0,153-1,931)$ \\
\hline
\end{tabular}

Keterangan: Analisis menggunakan Uji Chi-Square; OR = Odd Ratio 95\% Cl = Confident Interval 95\%

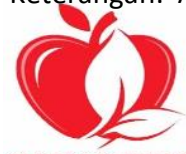

(C)2019. Nurmayasanti dan Mahmudiono. Open access under CC BY - SA license.

Received: 06-02-2019, Accepted: 11-04-2019, Published online: 01-6-2019.

doi: 10.20473/amnt.v3.i2.2019.114-121, Joinly Published by IAGIKMI \& Universitas Airlangga 
Faktor yang mungkin menjadi penyebab tidak terlihat perbedaan dalam jumlah kasus dan control pada penelitian ini adalah jumlah sampel yang sedikit sehingga tidak dapat menggambarkan perbedaan antara kasus stunting dan non-stunting.

Namun jumlah stunting pada balita perempuan yang menunjukkan angka yang lebih tinggi dibandingkan balita stunting laki-laki mungkin disebabkan oleh beberapa faktor, diantaranya pemberian makan yang kurang memenuhi asupan gizi atau faktor lingkungan yang tidak sehat sehingga terkena penyakit infeksi. Hal ini sama dengan hasil penelitian di Semarang Timur yang mana kasus stunting lebih banyak dialami oleh balita perempuan daripada balita laki-laki ${ }^{19}$. Pada penelitian ini (tabel 2) menunjukkan bahwa balita perempuan lebih beragam jenis makanannya, dan berdasarkan skor keragaman pangan, balita perempuan cenderung lebih tinggi skornya dibandingkan balita laki-laki. Walaupun masih terlihat jenis makanan daging organ (jeroan) tidak dikonsumsi oleh balita perempuan. Berdasarkan pengambilan data food recall balita laki-laki cenderung lebih sering mengkonsumsi makanan ringan sehingga jenis makanannya kurang beragam.

Karakteristik balita yang dilihat dari riwayat pemberian ASI ekslusif berdasarkan tabel 1 menunjukkan bahwa balita stunting dan non-stunting cakupannya hampir sama yaitu $19,6 \%$ dan $17,9 \%$. Namun terlihat bahwa proporsi balita non-stunting lebih banyak yang tidak mendapatkan ASI eksklusif dibandingkan balita stunting. Praktek pemberian ASI eksklusif yang tidak berjalan pada keluarga balita disebabkan kurangnya pengetahuan ibu tentang pentingnya ASI eksklusif terutama untuk meningkatkan daya tahan tubuh bayi terhadap penyakit infeksi selain itu juga kurangnya dukungan dari keluarga untuk melakukan pemberian ASI eksklusif kepada bayi. Penelitian yang dilakukan oleh Gunawan et al (2016) menunjukkan bahwa ASI eksklusif bukan merupakan satu-satunya faktor yang berkontribusi dalam masalah stunting pada anak-anak ${ }^{20}$. Masalah stunting pada balita mungkin tidak disebabkan oleh kecukupan gizi saja, baik dari pemberian ASI eksklusif atau makanan pendamping $\mathrm{ASI}$, tapi juga harus mempertimbangkan kualitas makanan pendamping ${ }^{21}$. Tabel 1 menunjukkan bahwa pendidikan ibu dalam penelitian ini baik itu ibu balita stunting dan non-stunting adalah berpendidikan dasar $(28,6 \%)$. Ibu dengan pendidikan dasar belum tentu memiliki anak yang mengalami stunting dan ibu yang memiliki pendidikan menengah juga belum tentu memiliki anak yang tidak stunting. lbu yang berpendidikan dasar maupun menengah mungkin sudah mendapatakan pengetahuan tentang gizi melalui sosialisasi dan edukasi di Posyandu sehingga ibu dapat menerapkan pengetahuannya dalam memberikan pola asuh khususnya dalam hal pemberian makan pada balita. Penelitian di Kota Semarang menunjukkan bahwa tidak ada hubungan antara tingkat pendidikan ibu dengan stunting pada balita ${ }^{22}$. Stunting terjadi pada anak usia di bawah lima tahun yang sering kali merupakan akibat dari asupan gizi yang kurang dan infeksi yang berulang serta merupakan cerminan status gizi pada masa lampau 23,24 . Pada penelitian lain yang dilakukan di Kabupaten Bojonegoro juga menyatakan bahwa tidak ada hubungan antara tingkat pendidikan ibu dengan stunting pada balita keluarga miskin di Kecamatan Balen, Bojonegoro ${ }^{24}$. Tingkat pendidikan ibu adalah akar dari masalah kurang gizi dan masih banyak sebab lain yang mempengaruhi maslaah kurang gizi ${ }^{24}$

Pada penelitian ini sebagian besar status pekerjaan ibu adalah tidak bekerja (76,8\%). Ibu yang tidak bekerja memiliki balita yang mengalami stunting sebanyak $35,7 \%$ dan balita yang tidak stunting juga hampir sama yaitu $41,1 \%$. Ibu yang tidak bekerja akan lebih perhatian terhadap pola asuh anak dibandingkan dengan ibu yang bekerja. Pada penelitian ini ibu yang bekerja rata-rata bekerja sebagai pedagang atau buruh di perkebunan bawang merah sehingga akses untuk mendapatkan informasi atau pengetahuan tentang gizi dan kesehatan tergolong kurang. Jenis pekerjaan ibu mungkin juga berkaitan dengan tingkat pendidikan ibu yang mana sebagian besar memiliki tingkat pendidikan dasar (SD dan SMP) sehingga akses untuk mendapatkan informasi tentang pencegahan stunting atau gizi seimbang tergolong kurang. Ibu yang tidak bekerja memiliki kesempatan dan waktu yang lebih banyak untuk menyiapkan makanan anaknya sehingga kebutuhan makanan anak lebih terpenuhi dibandingkan ibu yang bekerja. Pendapatan keluarga yang ditunjukkan pada tabel 2 terlihat bahwa sebanyak 39,3\% keluarga balita yang mengalami stunting memiliki penghasilan rendah. Uji statistik menunjukkan bahwa pendapatan keluarga memiliki hubungan yang signifikan dengan kejadian stunting pada balita $(p=0,048)$ dan odd ratio juga menunjukkan bahwa pendapatan keluarga yang rendah berisiko 3,178 kali lebih besar terkena stunting.

Tabel 2. Hubungan Tingkat Pendapatan dan Keragaman Pangan Dengan Kejadian Stunting

\begin{tabular}{|c|c|c|c|c|c|c|c|c|}
\hline \multirow[b]{2}{*}{ Variabel } & \multicolumn{2}{|c|}{ Stunting } & \multicolumn{2}{|c|}{ Non-Stunting } & \multicolumn{2}{|c|}{ Total } & \multirow{2}{*}{$\begin{array}{c}p- \\
\text { value }\end{array}$} & \multirow{2}{*}{$\begin{array}{c}\text { OR } \\
(95 \% \mathrm{Cl})\end{array}$} \\
\hline & $\mathrm{n}$ & $\%$ & $\mathrm{n}$ & $\%$ & $\mathrm{n}$ & $\%$ & & \\
\hline \multicolumn{9}{|l|}{ Pendapatan Keluarga } \\
\hline Rendah & 22 & 39,3 & 15 & 26,8 & 37 & 66,1 & $0,048^{*}$ & 3,178 \\
\hline Tinggi & 6 & 10,7 & 13 & 23,2 & 19 & 33,9 & & $(0,987-10,228)$ \\
\hline \multicolumn{9}{|l|}{ Makanan Beragam } \\
\hline Tidak Beragam (Skor IDDS & 11 & 19,6 & 11 & 19,6 & 22 & 39,2 & & \\
\hline$<4)$ & & & & & & & 1,000 & 1,000 \\
\hline Beragam (Skor IDDS $\geq 4$ ) & 17 & 30,4 & 17 & 30,4 & 34 & 60,8 & & $(0,342-2,923)$ \\
\hline
\end{tabular}

Keterangan: Analisis menggunakan Uji Chi-Square ; OR = Odd Ratio 95\% Cl = Confident Interval 95\% Tanda* menunjukkan adanya hubungan signifikan dengan nilai $p<0,05$ 
Tabel 3. Distribusi Konsumsi Pangan Balita Laki-Laki dan Perempuan

\begin{tabular}{|c|c|c|c|c|c|c|c|c|c|}
\hline \multirow[b]{2}{*}{ Balita } & \multicolumn{9}{|c|}{ Skor Kelompok Pangan (\%) } \\
\hline & Serealia & $\begin{array}{c}\text { Kacang- } \\
\text { kacangan }\end{array}$ & Jeroan & $\begin{array}{l}\text { Daging } \\
\text { \& Ikan }\end{array}$ & Telur & $\begin{array}{c}\text { Buah/sayur } \\
\text { vitamin A }\end{array}$ & $\begin{array}{c}\text { Buah/sayur } \\
\text { lain }\end{array}$ & $\begin{array}{c}\text { Sayuran } \\
\text { hijau }\end{array}$ & Susu \\
\hline Laki-laki & 42.31 & 22.44 & 1.92 & 13.46 & 17.31 & 7.69 & 10.90 & 10.90 & 26.28 \\
\hline Perempuan & 65.38 & 42.95 & 0.00 & 21.15 & 25.64 & 17.95 & 15.38 & 27.56 & 30.13 \\
\hline
\end{tabular}

Hal ini sejalan dengan penelitian di Semarang Timur yang menunjukkan bahwa pendapatan adalah salah faktor risiko kejadian stunting pada balita ${ }^{19}$. Penelitian penelitian juga menunjukkan bahwa pendapatan keluarga yang rendah berisiko 3,92 kali lebih besar menghasilkan anak yang stunting ${ }^{12}$. Pendapatan keluarga yang tinggi dapat memenuhi kebutuhan keluarga terutama kebutuhan pangan yang beragam, sehingga asupan makanan balita tercukupi. Keluarga yang memiliki akses ekonomi dan pemenuhan kebutuhan yang cukup akan berpengaruh terhadap meningkatknya kualitas konsumsi pangan anggota keluarga yang merupakan gambaran dari perilaku gizi yang baik 25

Keragaman makanan adalah ukuran konsumsi makanan yang bersifat kualitatif dan mencerminkan akses rumah tangga dalam mendapatkan berbagai macam makanan ${ }^{26}$. Keragaman pangan juga salah satu kunci dari diet yang berkualitas dan diperkirakan dapat meningkatkan tersedianya kebutuhan gizi esensial untuk meningkatkan kesehatan ${ }^{27}$. Berdasarkan data demografi dan survey kesehatan Indonesia tahun 2012, praktik pemberian makan pada bayi dan balita antara anak-anak usia 6-23 bulan menunjukkan 54,2\% mengonsumsi daging/ikan/ayam, 48,3\% mengonsumsi telur dan $8,8 \%$ mengonsumsi susu28. Dalam hal keragaman pangan, $58,2 \%$ anak-anak mengonsumsi $\geq 4$ kelompok pangan ${ }^{28}$. Kelompok rawan seperti bayi, balita dan anak yang sedang dalam masa pertumbuhan serta ibu hamil dan ibu menyusui membutuhkan protein dalam jumlah besar sehingga kebutuhan juga meningkat ${ }^{29}$.

Pada penelitian Paramashanti et al (2017) keragaman pangan individu yang berkaitan dengan stunting secara khusus terlihat pada status ekonomi paling rendah ${ }^{21}$. Keragaman pangan tercermin dari daya beli masyarakat terhadap jenis makanan ${ }^{21}$. Selain itu juga menunjukkan bahwa keragaman makanan individu berkaitan erat dengan kejadian stunting pada bayi dan anak-anak usia 6-23 bulan ${ }^{21}$. Bayi dan anak-anak yang konsumsi keragaman makanannya rendah $(<4$ kelompok pangan) memiliki risiko 16,67 kali mengalami stunting dibandingkan dengan yang mengonsumsi makanan beragam ( $\geq 4$ kelompok pangan $)^{21}$.

Pada tabel 2 menunjukkan bahwa keragaman pangan tidak berhubungan dengan stunting. Dari hasil uji statistik menunjukkan nilai $p=$ value 1,000 . Gambar 1 adalah skor rata-rata keragaman pangan antara balita stunting dan non-stunting yang diambil selama $3 \times 24$ jam secara tidak berurutan. Skor keragaman pangan diambil dari sembilan kelompok pangan, terdiri dari kelompok serealia, umbi dan makanan berpati; kacang-kacangan dan biji-bijian; daging organ/jeroan; daging dan ikan; telur; buah dan sayuran tinggi vitamin $A$; buah dan sayuran lainnya; sayuran hijau; susu dan olahannya ${ }^{26}$.
Balita stunting maupun non-stunting sama-sama memiliki skor yang rendah $(\leq 4)$, artinya keragaman pangan masih rendah atau tidak beragam jenis makanan yang dikonsumsi oleh balita. Bahkan dalam penelitian ini ditemukan balita non-stunting yang memiliki skor paling rendah yaitu 2. Namun, skor 4 hingga 6 dimiliki oleh kelompok balita non-stunting.

Pada tabel 1 terlihat bahwa balita stunting dan non-stunting yang mengonsumsi makanan beragam jumlahnya sama $(30,4 \%)$ begitu pula dengan skor makanan tidak beragam jumlahnya juga sama $(19,6 \%)$. Pada gambar 2 terlihat bahwa skor tertinggi yang dikonsumsi oleh balita stunting dan non-stunting adalah jenis pangan serealia $(53,85 \%)$ hal ini terjadi karena komoditi utama kabupaten Nganjuk serta bahan makanan pokok yang dikonsumsi adalah beras (serealia). Gambar 2 juga memperlihatkan bahwa balita nonstunting cenderung lebih banyak mengkonsumsi jenis pangan sayuran, baik itu sayuran yang kaya vitamin $A$ dan sayuran hijau dibandingkan jenis pangan hewani. Sedangkan sumber protein hewani, balita non-stunting lebih banyak mengkonsumsi susu.

Berbeda dengan balita non-stunting, balita stunting dari gambar 1 terlihat lebih beragam makanannya, walaupun persentase jenis pangan yang dikonsumsi ada yang lebih rendah dari balita nonstunting, namun balita stunting mengkonsumsi semua jenis pangan tersebut. Persentase skor konsumsi sayursayuran pada balita stunting lebih rendah daripada balita non-stunting karena balita stunting cenderung lebih menyukai lauk hewani daripada sayuran. Konsumsi susu pada kedua kelompok balita sama-sama memiliki skor yang cukup tinggi dibandingkan makanan sumber protein ataupun sayuran. Susu diberikan oleh orangtua kepada balita nya untuk menggantikan makanan yang mungkin kurang disukai oleh anak.

Sebagaimana dalam penelitian Pangesti tahun 2017 bahwa balita di wilayah agroekologi memiliki preferensi yang tinggi terhadap konsumsi susu, namun balita di wilayah ini cenderung memiliki nafsu makan terhadap makanan berat sehingga orangtua memberikan tambahan makanan berupa susu ${ }^{30}$. Keragaman pangan dipengaruhi oleh faktor kesukaan yang dapat dilihat dari daya terima yang menjadi kebiasaan konsumsi makanan pada balita 25

Hasil skor keragaman pangan (tabel 2) dari dua kelompok balita tersebut dapat dilihat juga dari uji Chisquare yang didapatkan hasil bahwa tidak ada hubungan antara keragaman pangan balita stunting dan nonstunting $(p=1,000)$. Begitu juga dengan hasil odd ratio yang menunjukkan bahwa keragaman pangan bukanlah faktor risiko balita stunting $(\mathrm{OR}=1,00095 \% \mathrm{Cl}=0,342$ $2,923)$. 


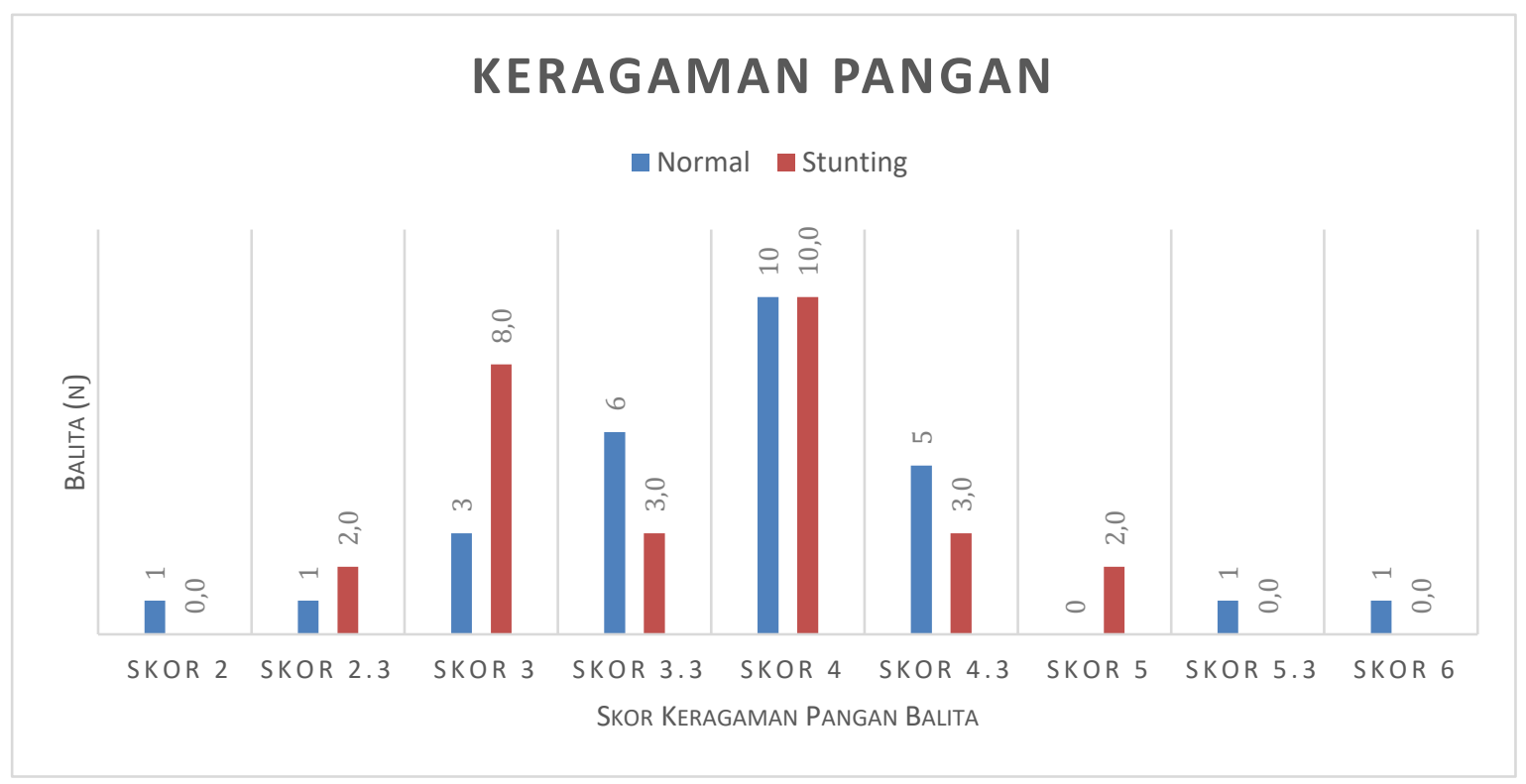

Gambar 1. Skor Keragaman Pangan Balita

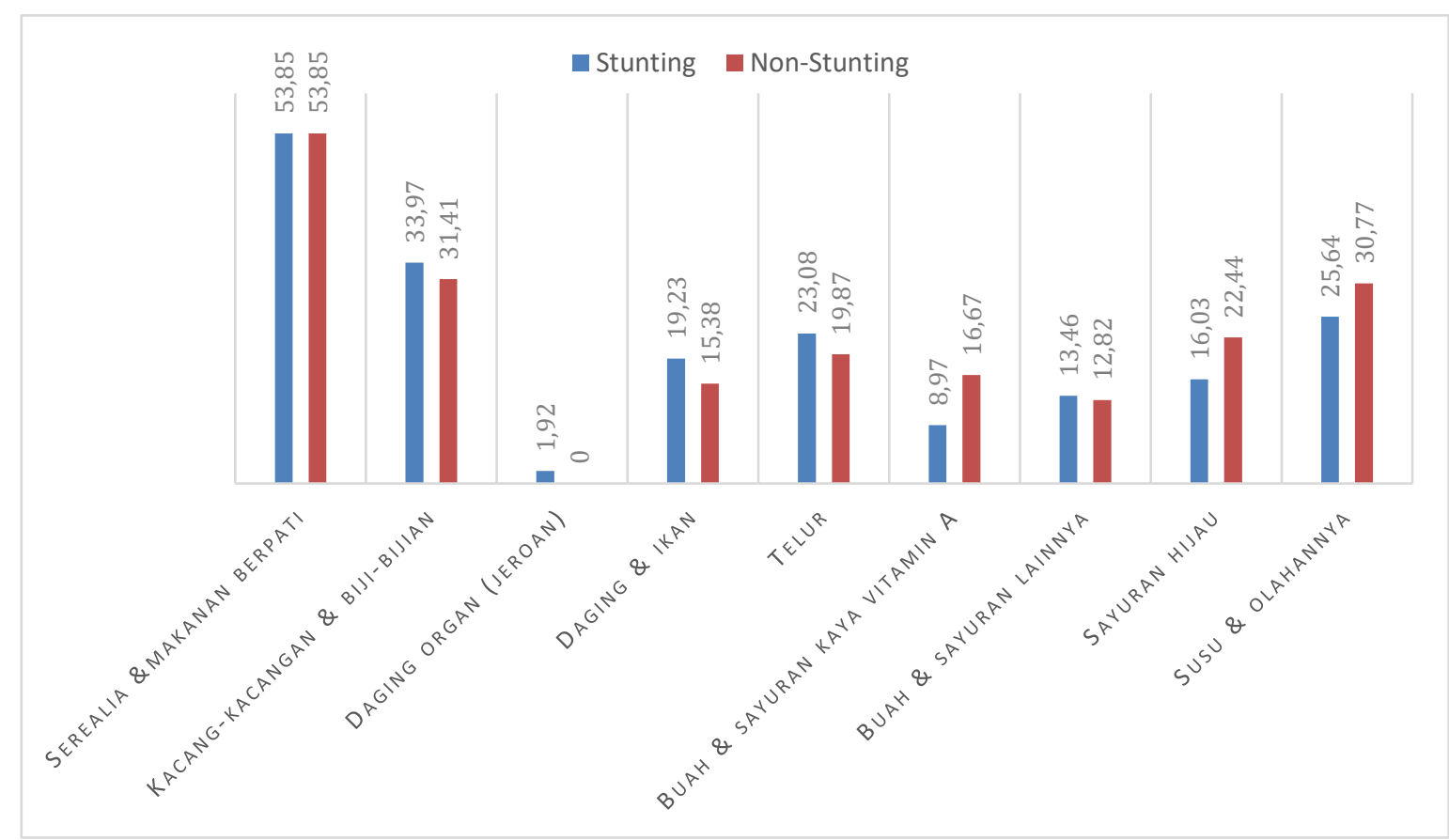

Gambar 2. Persentase Kelompok Pangan Yang Dikonsumsi Balita Stunting dan Non-Stunting

Balita stunting lebih banyak mengkonsumsi makanan beragam mungkin karena ibu atau pengasuh yang memiliki balita stunting sudah terpapar informasi di Pos Pelayanan Terpadu (Posyandu) tentang stunting dan pencegahannya ataupun upaya tumbuh kejar pertumbuhannya, termasuk pemberian makanan dengan gizi seimbang.

Ibu balita yang sebagian besar adalah ibu rumah tangga memiliki waktu yang banyak untuk mempersiapkan makanan balita serta dapat rutin datang ke Posyandu untuk memantau pertumbuhan balita.
Posyandu dapat menjadi salah satu sarana ibu balita untuk mendapatkan pengetahuan gizi ${ }^{31}$.

Promosi kesehatan dan kampanye peningkatan kesadaran untuk memperhatikan pertumbuhan anakanak diperlukan untuk mengubah perilaku masyarakat ${ }^{32}$. Keragaman konsumsi pangan dipengaruhi oleh faktor internal dan eksternal. Adapun faktor internal antara lain pendapatan, preferensi, budaya, agama, pengetahuan tentang gizi, sedangkan faktor eksternal keragaman konsumsi pangan antara lain faktor agro-ekologi, produksi, ketersediaan dan distribusi, anekaragaman pangan, serta iklan ${ }^{33}$. 
Selain paparan infromasi dari Posyandu, hasil penelitian yang tidak berhubungan ini bisa disebabkan oleh pengambilan sampel yang jumlahnya sedikit atau karena karakteristik wilayah yang sama sehingga pemilihan bahan makanan dari kelompok balita stunting maupun non-stunting tidak jauh beda.

\section{KESIMPULAN}

Pada penelitian ini menunjukkan karakteristik balita yang mengalami stunting lebih banyak pada balita perempuan, sedangkan usia paling banyak mengalami stunting adalah usia 37-59 bulan. Proporsi pendidikan ibu balita stunting maupun non-stunting diketahui samasama memiliki tingkat pendidikan dasar. Sedangkan dari segi pekerjaan ibu diketahui bahwa kedua kelompok balita memiliki ibu yang tidak bekerja. Tingkat pendapatan keluarga menunjukkan adanya hubungan dengan kejadian stunting dan apabila berpendapatan rendah memiliki risiko terkena stunting pada balita. Skor keragaman pangan pada balita stunting maupun nonstunting dari hasil IDDS tergolong rendah. Maka diharapkan pemerintah melalui Dinas Kesehatan dan Dinas Pertanian menggalakkan program penganekaragaman pangan di Kabupaten Nganjuk. Serta memberikan sosialisasi berupa promosi kesehatan mengenai pencegahan dan upaya tumbuh kejar balita stunting pada masyarakat khususnya wilayah prioritas stunting di Kabupaten Nganjuk.

\section{ACKNOWLEDGEMENT}

Penulis mengucapkan terima kasih kepada Kantor Bangsa dan Perlindungan Masyarakat Daerah Kabupaten Nganjuk, serta Puskesmas Wilangan. Ucapan terima kasih juga penulis sampaikan kepada dosen pembimbing yang telah memberikan bimbingannya serta kepada seluruh civitas akademika Program Studi S1 Gizi Universitas Airlangga.

\section{REFERENSI}

1. Adriani, M. \& Wirjatmadi, B. Gizi dan Kesehatan Balita Peranan Mikro Zink Pada Pertumbuhan Balita. (Kencana Prenadamedia Group, 2014).

2. Grantham-mcgregor, S. et al. Child development in developing countries 1 Developmental potential in the fi rst 5 years for children in. Lancet 369, 60-70 (2007).

3. Naylor, R. L. The Many Faces of Food Security. in The Evolving Sphere of Food Security (ed. Naylor, R. L.) (Oxford University Press, 2014).

4. Kemenkes. Hasil Utama RISKESDAS 2018. (2018).

5. Kementerian Kesehatan. Riset Kesehatan Dasar (RISKESDAS) 2013. Laporan Nasional 2013 (2013). doi:1 Desember 2013

6. WHO. Nutrition Landscape Information System. Nutrition Landacape Information System (WHO Document Production Services, 2010). doi:10.1159/000362780.Interpretation

7. MCA Indonesia. Stunting dan Masa Depan Indonesia. Millennium Challenge Account Indonesia (Millenium Challenge Indonesia, 2013).
8. Kemenkes. Situasi Balita Pendek (Stunting) di Indonesia. (2018).

9. Kemenkes RI. Pedoman gizi seimbang. (2014).

10. Motbainor, A., Worku, A. \& Kumie, A. Stunting Is Associated with Food Diversity while Wasting with Food Insecurity among Underfive Children in East and West Gojjam Zones of Amhara Region , Ethiopia. PLoS One 10, 1-14 (2015).

11. Darapheak, C., Takano, T., Kizuki, M., Nakamura, K. \& Seino, K. Consumption of animal source foods and dietary diversity reduce stunting in children in Cambodia. Int. Arch. Med. 6, 2-11 (2013).

12. Kusumawati, E., Rahardjo, S. \& Sari, H. P. Model Pengendalian Faktor Risiko Stunting pada Anak Usia di Bawah Tiga Tahun Model. J. Kesehat. Masy. Nas. 9, 249-256 (2015).

13. Kemenkes. Upaya Percepatan Penurunan Stunting. (2018).

14. FAO. Guidelines for measuring household and individual dietary diversity. Fao (2010).

15. MGoudet, S., Griffiths, P. L., Bogin, B. A. \& Madise, N. J. Nutritional interventions for preventing stunting in children ( 0 to 5 years) living in urban slums in low and middle-income countries ( LMIC ) ( Protocol ). Cochrane Database ofSystematic Rev. (2018). doi:10.1002/14651858.CD011695.www.cochran elibrary.com

16. Victora, C. G., de Onis, M., Hallal, P. C., Blossner, M. \& Shrimpton, R. Worldwide Timing of Growth Faltering: Revisiting Implications for Interventions. Pediatrics 125, e473-e480 (2010).

17. Golden, M. Is complete catch-up possible for stunted malnourished. Eur. J. Clin. Nutr. 1, 58-71 (994).

18. Adair, L. S. \& Guilkey, D. K. Age-Specific Determinants of Stunting in Filipino Children. J. Nutr. 127, 314-320 (1997).

19. Nasikhah, R. \& Margawati, A. Faktor Risiko Kejadian Stunting Pada Balita Usia $24-36$ Bulan Di Kecamatan Semarang Timur. J. Nutr. Coll. 1, 176-184 (2012).

20. Paramashanti, B. A., Hadi, H. \& Gunawan, I. M. A. Pemberian ASI eksklusif tidak berhubungan dengan stunting pada anak usia $6-23$ bulan di Indonesia. J. Gizi dan Diet. Indones. 3, 162-174 (2015).

21. Paramashanti, B. A., Paratmanitya, Y. \& Marsiswati. Individual dietary diversity is strongly associated with stunting in infants and young children. J. Gizi Klin. Indones. 14, 19-26 (2017).

22. Anindita, P. Hubungan Tingkat Pendidikan Ibu, Pendapatan Keluarga, Kecukupan Protein \& Zinc Dengan Stunting (Pendek) Pada Balita Usia 6 - 35 Bulan Di Kecamatan Tembalang Kota Semarang. J. Kesehat. Masy. 1, 617-626 (2012).

23. Talukder, A. \& Razu, S. R. Factors Affecting Stunting Among Children Under Five Years Of Age In Bangladesh. Fam. Med. Prim. Care Rev. 20, 356-362 (2018).

24. Ni'mah, C. \& Muniroh, L. Hubungan Tingkat Pendidikan, Tingkat Pengetahuan Dan Pola Asuh 
Ibu Dengan Wasting Dan Stunting Pada Balita Keluarga Miskin. Media Gizi Indones. 10, 84-90 (2015).

25. Hardinsyah. Review Faktor Determinan Keragaman Konsumsi Pangan. J. Gizi dan Pangan 2, 55-74 (2007).

26. FAO. Guidelines For Measuring Household And Individual Dietary Diversity. FAO (2011). doi:613.2KEN

27. Muslimatun, S., Ade, L. \& Wiradnyani, A. Dietary diversity, animal source food consumption and linear growth among children aged $1-5$ years in Bandung , Indonesia: a longitudinal observational study. Br. J. Nutr. 116, s27-s35 (2016).

28. Statistik-BPS), S. I. (Badan P., (BKKBN), N. P. and F. P. B., (Kemenkes-MOH), K. K. \& International, I. Demographic and Health Survey 2012. (BPS, BKKBN, Kemenkes, and ICF International, 2013)

29. UI, FKM. Gizi dan Kesehatan Masyarakat. (PT RajaGrafindo Persada, 2010).
30. Pangesti, D. P., Andadari, S. \& Mahmudiono, T. Keragaman Pangan dan Tingkat Kecukupan Energi serta Protein Pada Balita. Amerta Nutr. 1, 172-179 (2017)

31. Prakoso, S. I. S. \& Mulyana, B. Keragaman Pangan dengan Status Kadarzi Keluarga di Wilayah Kerja Posyandu Sidotopo, Surabaya Dietary Diversity and Nutrition Concious Family ( Kadarzi ) Status among Household in Posyandu Sidotopo , Surabaya. Amerta Nutr. 219-227 (2018). doi:10.20473/amnt.v2.i3.2018.219-227

32. Iqbal, S., Zakar, R., Zakar, M. Z. \& Fischer, F. Factors associated with infants' and young children' s ( $6-23$ months ) dietary diversity in Pakistan: evidence from the demographic and health survey 2012 - 13. Nutr. J. 16, (2017).

33. Suryana, A. Penganekaragaman Konsumsi Pangan dan Gizi Faktor Pendukung Peningkatan Kualitas Sumber Daya Manusia. Jurnal Pangan $17,(2008)$. 